\title{
Nocturnal Serum Growth Hormone Concentration is not Augmented by Short-Term Testosterone Infusion in Pubertal Boys
}

\author{
CAROL M. FOSTER, NANCY J. HOPWOOD, JEANNE M. HASSING, PAULA M. HALE, \\ TARINA MENDES, ROBERT P. KELCH, AND INESE Z. BEITINS \\ Division of Pediatric Endocrinology, Department of Pediatrics, University of Michigan Medical School, \\ Ann Arbor, Michigan 48109
}

\begin{abstract}
Chronic exposure to testosterone (T) increases growth hormone (GH) secretion. To determine whether acute exposure to $T$ would also enhance $G H$ secretion, we infused saline, followed 1 wk later by $T$, for 18-24 $\mathrm{h}$ at one-third the adult male production rate in 12 pubertal boys and at the adult male production rate in eight additional pubertal boys. Blood was obtained every 20 min for GH and every $30 \mathrm{~min}$ for T from $2000-0800 \mathrm{~h}$. Though infusion significantly increased serum $T$ concentrations in all 20 boys, mean $\mathrm{GH}$ concentration, $\mathrm{GH}$ pulse frequency, and GH pulse amplitude did not increase compared to the saline infusion night. The secretory dynamics of GH as a function of 3-h time blocks from 2000-0800 $\mathrm{h}$ were also determined in the eight boys who received the higher dose of $T$. The profile for mean GH concentration, pulse frequency, pulse amplitude, and peak area were not affected by acute infusion of $T$ at concentrations sufficient to alter LH secretion. This suggests that, at least in pubertal boys, one must be exposed to $T$ for a period longer than 12-18 $\mathrm{h}$ to induce increased GH secretion. (Pediatr Res 26: 320 324,1989 )
\end{abstract}

\section{Abbreviations}

GH, growth hormone

$T$, testosterone

LH, luteinizing hormone

SmC, somatomedin C

$\mathrm{CV}$, coefficients of variation

It has long been established that $\mathrm{GH}$ is secreted episodically throughout the day with significant augmentation during sleep in children and adults (1-5). Inasmuch as most of the GH is secreted during the nighttime hours, GH secretion rates calculated on the basis of 24-h sampling correlate well with those calculated on the basis of 12-h nighttime sampling $(6,7)$. Overall GH pulse frequency and/or amplitude are known to be acutely affected by fasting (8) and the sex steroid milieu (9-11).

In children, treatment with androgens or estrogens has resulted in increased $\mathrm{GH}$ release to pharmacologic stimuli (12-14). GH

Received March 10, 1989; accepted May 24, 1989.

Correspondence Carol M. Foster, M.D., D3252 Medical Professional Building, Box 0718,1500 E. Medical Center Drive, Ann Arbor, MI 48109-0718.

Supported by grants from the National Institutes of Health (HD-16000 and HD18515) and the General Clinical Research Centers of the National Institutes of Health (5MO1RR00042). P.M.H. was supported in part by a USPHS Endocrinology Metabolism training Grant AM-07245 and J.H. was supported by a USPHS Reproductive Endocrinology training Grant HD-07048. pulse amplitude but not frequency is increased by $T$ treatment of at least 3 mo duration $(10,15)$. Therapy with $T$ enanthate in boys with constitutional delay in growth and low GH secretion results in increased $\mathrm{GH}$ secretion as well as acceleration of growth velocity $(10,16,17)$. It therefore appears that the growth acceleration during spontaneous puberty may be related to the effects of sex steroids upon GH secretion as well as direct effects of sex steroids on tissues.

We studied GH secretion before and during $\mathrm{T}$ infusion in 20 early to midpubertal boys to determine whether the acute elevation of $\mathrm{T}$ to concentrations known to alter $\mathrm{LH}$ secretion (18, 19 ), would also affect the neuroendocrine signals regulating $\mathrm{GH}$ secretion. Mean integrated $\mathrm{GH}$ concentrations were calculated from $12-\mathrm{h}$ nocturnal serum samples obtained every $20 \mathrm{~min}$ during a saline infusion night and compared to the results obtained during a $\mathrm{T}$ infusion night. $\mathrm{T}$ was administered at onethird of the adult male blood production rate in 12 boys and at the adult male production rate in eight boys.

\section{MATERIALS AND METHODS}

Subjects. The clinical characteristics and diagnoses of the 20 boys studied are listed in Table 1 . All boys (with the exception of patient 20) had delayed adolescent development and 17 of the 20 had ht less than the fifth percentile for age. When ht percentiles were corrected for bone age, no ht was more than 2 SD from the mean. SmC levels, bone age $\mathrm{x}$-rays, and thyroid function tests had been determined within the 3 mo before the study. Thyroid function was normal in all boys. All boys had participated in studies of $\mathrm{LH}$ secretion in response to $\mathrm{T}$ infusion, and these results are reported elsewhere $(18,19)$. Peak GH concentrations in response to arginine $(0.5 \mathrm{~g} / \mathrm{kg}$ intravenous over $30 \mathrm{~min})$, insulin $(0.1 \mathrm{U} / \mathrm{kg}$ intravenous), after $15 \mathrm{~min}$ of exercise or $1 \mathrm{~h}$ after onset of sleep are also shown in Table 1. Patient 9 had a peak GH response to two provocative stimuli of $7.8 \mu \mathrm{g} / \mathrm{L}$ and therefore may have had partial $\mathrm{GH}$ deficiency by modern criteria. Patient 18, who had the lowest overnight mean GH concentration, declined further evaluation. Patient 12, who had a peak screening $\mathrm{GH}$ value of $3.9 \mu \mathrm{g} / \mathrm{L}$, had a normal pubertal growth velocity $(10 \mathrm{~cm} / \mathrm{y})$.

Protocol. All study protocols and consent procedures were approved by the University of Michigan Institutional Review Board. Studies were performed on two consecutive weekends in the Clinical Research Center of the University of Michigan after written informed consent was obtained from a parent and assent obtained from the subject. On each study weekend, boys spent 2 nights in the center. Studies were performed on the second night to allow for acclimatization. On the second day, intravenous cannulae were inserted in each forearm. Lights were turned off at $2200 \mathrm{~h}$, and sleep was monitored by trained nursing personnel. 
Table 1. Clinical characteristics and study protocol

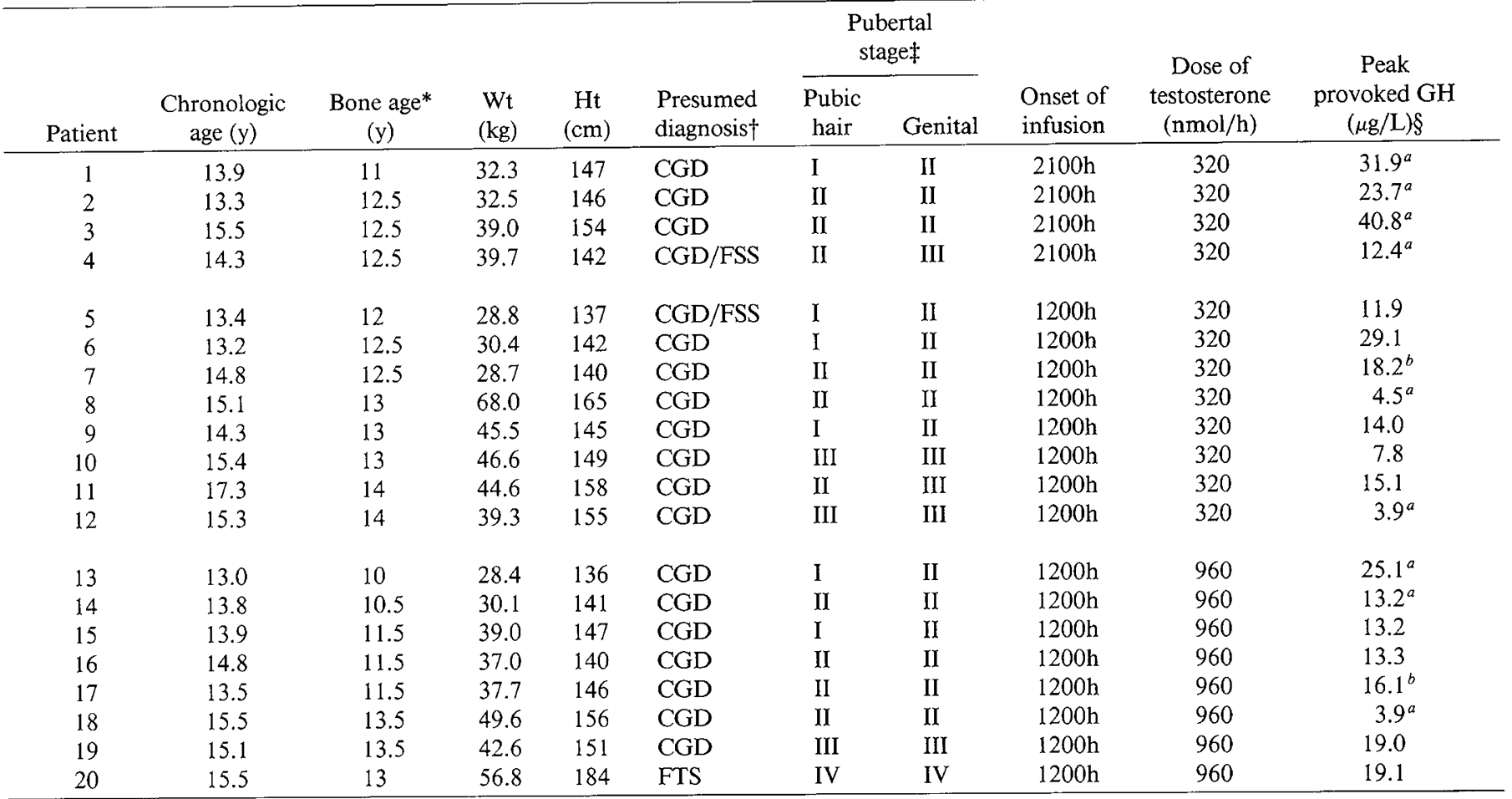

* By the method of Greulich and Pyle (20).

† CGD, constitutional growth delay; FSS, familial short stature; FTS, familial tall stature.

$\$$ By the method of Tanner (21).

$\S$ Data followed by $a$ represents values $1 \mathrm{~h}$ after sleep. Data followed by $b$ are values obtained after exercise. All other values are peaks after arginine or insulin administration.

On the first weekend each boy received a $150 \mathrm{mmol}$ saline bolus at a volume matching the $\mathrm{T}$ bolus given on the second weekend ( $10 \mathrm{ml}$ in patients $1-13$ and $3 \mathrm{~mL}$ in patients $14-20)$. The bolus was administered at either $2100 \mathrm{~h}$ (patient 1-4) or $1200 \mathrm{~h}$ (patients 5-20) followed by a $150 \mathrm{mmol}$ saline infusion at 10 $\mathrm{mL} / \mathrm{h}$ continuing through the end of serial blood sampling at $0800 \mathrm{~h}$ the next morning. On the second weekend, T was infused at $10 \mathrm{~mL} / \mathrm{h}$. The infusate was prepared as described previously (18) from crystalline T obtained from Sigma Chemical Co. (St. Louis, MO) at a final concentration of $32 \mu \mathrm{mol} / \mathrm{L}$ (patients 112) or $96 \mu \mathrm{mol} / \mathrm{L}$ (patients $13-20$ ). All boys received a $320 \mathrm{nmol}$ bolus of T except for patient 13 who received $960 \mathrm{nmol}$. The bolus was given at $2100 \mathrm{~h}$ (patients 1-4) or $1200 \mathrm{~h}$ (patients 520). $\mathrm{T}$ was then infused at $10 \mathrm{ml} / \mathrm{h}$ at the doses indicated in Table 1. Blood was obtained from $2000-0800 \mathrm{~h}$ every $20 \mathrm{~min}$ for GH and every $30 \mathrm{~min}$ for T. Estradiol was also determined in three boys (patients 17-19) every $2 \mathrm{~h}$ from $2000-0800 \mathrm{~h}$.

Hormone measurements. Serum GH concentrations were measured in duplicate by a modified double antibody RIA as described previously (22). The standard was human pituitary $\mathrm{GH}$ obtained from the National Hormone and Pituitary Program. The assay sensitivity was $0.5 \mu \mathrm{g} / \mathrm{L}$ and the intra- and interassay $\mathrm{CV}$ were both less than $5 \%$. Serum $\mathrm{T}$ and estradiol were determined in duplicate by RIA using kits obtained from Radioassay Systems Laboratories, Inc. (Carson, CA). The T assay sensitivity was $0.35 \mathrm{nmol} / \mathrm{L}$ and the intra- and interassay $\mathrm{CV}$ were 5 and $8.5 \%$, respectively. The estradiol assay sensitivity was $18 \mathrm{pmol} / \mathrm{L}$ and the intra- and interassay $\mathrm{CV}$ were 8 and $15 \%$, respectively. SmC was determined commercially through the laboratories of SmithKline Diagnostics Inc. (Sunnyvale, CA). All samples from a subject (saline and $T$ infusion nights) were processed within the same assay.

Statistical analysis. GH pulses, peak amplitude, and total pulse area were determined using the Detect method of Oerter et al. (23). The false-positive peak detection level was set at less than
$0.1 \%$ using the predicted variance model. All values less than assay sensitivity were assigned a value of assay sensitivity. Missing values comprised less than $1 \%$ of the total sample and were not replaced. Peak amplitudes were derived by calculating the difference between peak height and the prepeak nadir. Peak area was calculated by the program (area under the curve).

All hormone values were transformed logarithmically. Mean $\mathrm{GH}$ values were subjected to one- or two-way analysis of variance for repeated measures for within or between treatment comparisons, respectively. Comparison of GH peak frequency and amplitude between treatments was by Student's paired $t$ test. Correlations were made using the Kendall rank correlation coefficient. A $p$ level of 0.05 was considered significant. The data are presented as the means $\pm \mathrm{SE}$.

\section{RESULTS}

Mean serum GH concentrations and GH secretory profiles. Mean GH and T concentrations from 2000 to $0800 \mathrm{~h}$, the number of $\mathrm{GH}$ pulses, mean GH pulse amplitude, and total pulse area during saline and $T$ infusion are shown in Table $2 . T$ infusion at $320 \mathrm{nmol} / \mathrm{h}$ produced a 2 -fold increase in nocturnal $\mathrm{T}$ concentration compared to the saline infusion night (patients $1-12$ ), and at $960 \mathrm{nmol} / \mathrm{h}$, produced a 5 -fold increase (patients 13-20). Serum estradiol determined in three boys (patients 1719) who received a $960 \mathrm{nmol} / \mathrm{h} \mathrm{T}$ infusion, did not increase above the assay detection limit $(18 \mathrm{pmol} / \mathrm{L})$ on the $\mathrm{T}$ infusion night.

On the saline night, mean $\mathrm{GH}$ concentration for all 20 boys was $3.4 \pm 0.5 \mu \mathrm{g} / \mathrm{L}$. Peak frequency was $3.6 \pm 0.2$ pulses $/$ boy/ $12 \mathrm{~h}$. In the four boys who received $\mathrm{T}$ at $320 \mathrm{nmol} / \mathrm{h}$ beginning at $2100 \mathrm{~h}$, the $12 \mathrm{~h}$ mean GH concentration was $4.2 \pm 1.1 \mu \mathrm{g} /$ L. Mean pulse amplitude and total pulse area were $10.7 \pm 2.4$ and $180.2 \pm 59.5 \mu \mathrm{g} / \mathrm{L}$, not significantly different than values 
Table 2. GH concentration and pulse characteristics and T concentration during saline and $T$ infusion

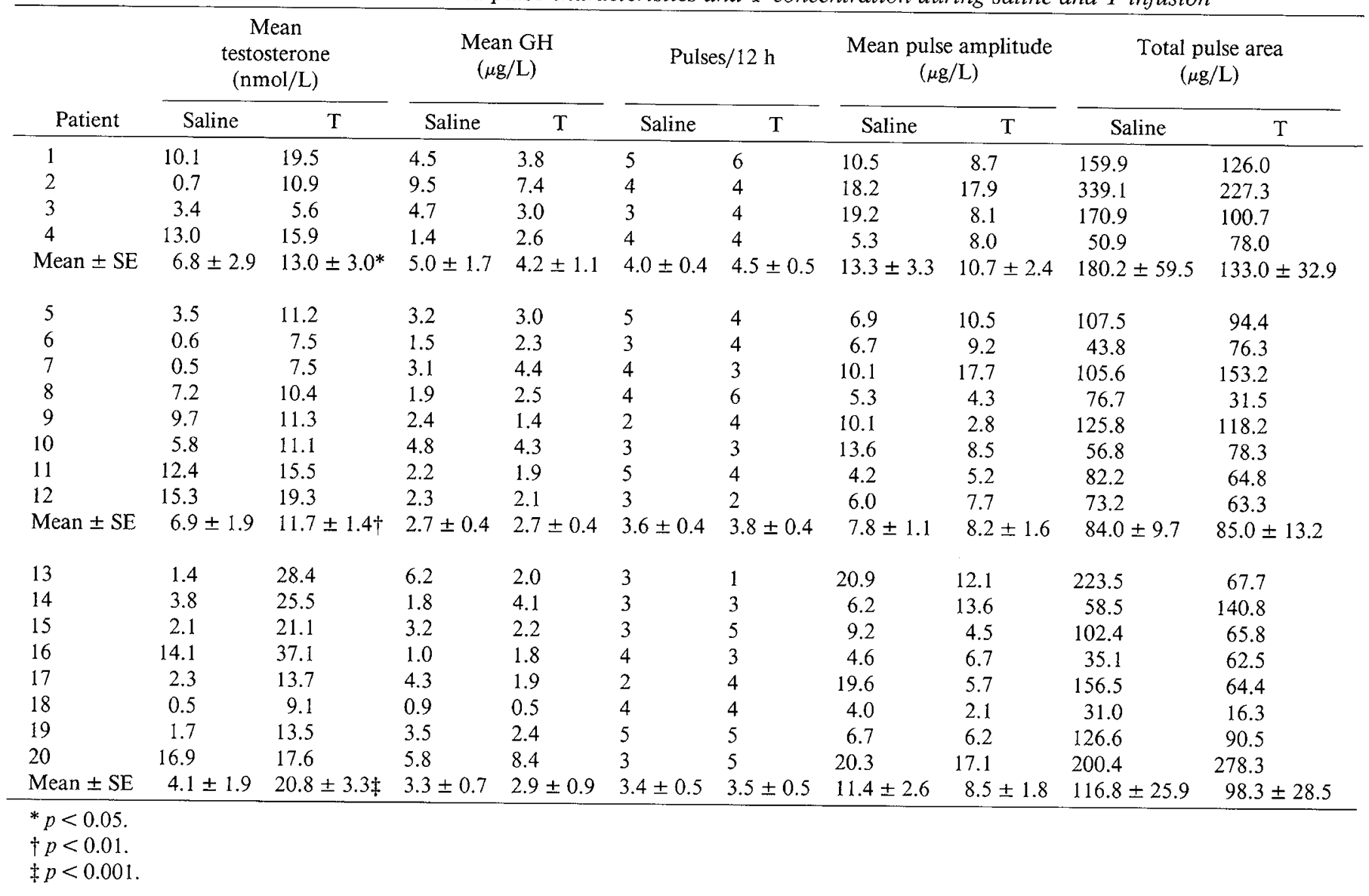

obtained during their saline infusion night. Eight additional boys received a $T$ infusion of $320 \mathrm{nmol} / \mathrm{h}$ beginning at $1200 \mathrm{~h}$. Mean $\mathrm{GH}$ concentration for these boys was $2.7 \pm 0.4 \mu \mathrm{g} / \mathrm{L}$ and mean pulse amplitude and total area were $7.8 \pm 1.1$ and $84.0 \pm 9.7$ $\mu \mathrm{g} / \mathrm{L}$, respectively. These values were similar to those obtained on their saline infusion night.

Inasmuch as $\mathrm{T}$ infusion at $320 \mathrm{nmol} / \mathrm{h}$ did not increase $\mathrm{GH}$ concentration, eight boys were treated with a $\mathrm{T}$ infusion of 960 $\mathrm{nmol} / \mathrm{h}$, a dose that approximates that produced by adult men (24). The mean $\mathrm{GH}$ concentration $(3.3 \pm 0.7 \mu \mathrm{g} / \mathrm{L})$ on the saline night, did not change significantly with $\mathrm{T}$ infusion $(2.9 \pm 0.9 \mu \mathrm{g} /$ L). Mean GH pulse amplitude and total pulse area were also unchanged. The dynamics of $\mathrm{GH}$ secretion with respect to time could conceivably have been altered by $\mathrm{T}$ administration. To examine this possibility, $\mathrm{GH}$ in the boys who received $960 \mathrm{nmol} /$ h $\mathrm{T}$ was analyzed in 3 -h time blocks. The $2000-2240 \mathrm{~h}$ block represented hours before the onset of sleep. The $2300-0140 \mathrm{~h}$ block encompassed the time when most boys fell asleep. As expected, mean $\mathrm{GH}$ concentration, pulse amplitude, and area were highest during this time block (Table 3). Although mean GH pulse amplitude and peak area were somewhat lower with $\mathrm{T}$ infusion when compared to saline infusion, the differences were not significant. Acute $\mathrm{T}$ infusion did not enhance $\mathrm{GH}$ secretion.

Somatomedin $C$ and $G H$. Mean SmC concentration, determined in 17 of the 20 boys, was $103 \pm 15$ (range $37-276$ ) $\mu \mathrm{g} / \mathrm{L}$. Mean GH pulse area correlated positively with SmC concentration $(\mathrm{z}=2.357, p<0.01)$. SmC concentration was also positively correlated with patient wt $(\mathrm{z}=2.033, p<0.05)$ and pubertal stage $(\mathrm{z}=2.927, p<0.01)$, but not with mean $\mathrm{T}$ concentration $(\mathrm{z}=1.286)$ or ht $(\mathrm{z}=1.291)$. Mean $\mathrm{GH}$ concentration and pulse amplitude did not show a significant correlation with ht, wt, pubertal stage, $\mathrm{T}$, or $\mathrm{SmC}$ concentration.

\section{DISCUSSION}

In our study, we have determined the overnight GH secretory patterns for 20 boys before and during an acute $T$ infusion. Although chronic $T$ treatment increases $G H$ secretion $(10,15)$ and $\mathrm{GH}$ concentration increases with the later stages of pubertal development $(4,5)$, we did not find an acute effect of $\mathrm{T}$ infusion on either mean $\mathrm{GH}$ concentration or on the $\mathrm{GH}$ secretory pattern. In contrast, we have found that $T$ infusion decreases nocturnal plasma LH concentration within 5-6 h (18), and T infusion at adult male production rates for periods at least as short as $12 \mathrm{~h}$ abolishes the nocturnal amplification of plasma LH concentration and LH pulse frequency (19). Thus, although LH secretion can be decreased acutely by infusion of T, GH secretion is relatively resistant to alteration by short-term $T$ infusion even at adult male blood production rates. If it is correct that $\mathrm{T}$ in puberty is responsible for increased $\mathrm{GH}$ concentration, a time lag between the plasma $T$ rise and an increase in $\mathrm{GH}$ secretion may be due to either a time-dependent induction of pituitary synthesis of $\mathrm{GH}$ or the time-dependent metabolism of $T$ to other steroids before its effects on the hypothalamic-pituitary axis can be seen.

Stress of hospitalization may have increased GH secretion on the first weekend. If the boys experienced less stress on the second weekend, GH secretion could have been reduced thereby masking a $\mathrm{T}$ induced increase in serum $\mathrm{GH}$ concentration. The study was deliberately nonrandom in the order of saline or $T$ administration. Saline was always given on the first weekend, because $T$ may have had a lingering effect on hormone secretion 1 wk later. To lessen the impact of the nonrandom study design, acclimatization nights were included on both study weekends. However, further studies, randomizing the saline and $\mathrm{T}$ order of 
Table 3. Effect of high dose testosterone infusion on $G H$ concentration and peak amplitude, area, and frequency as function of time

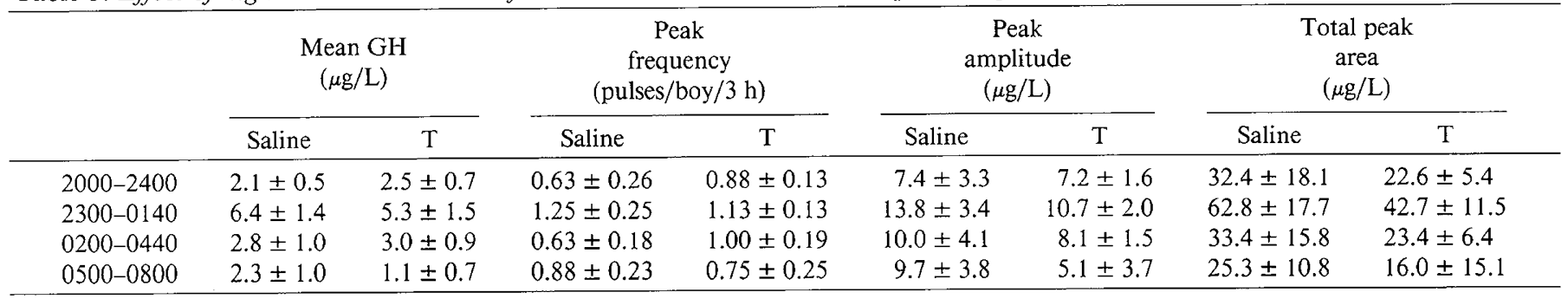

administration, will be necessary to prove absolutely that $\mathrm{T}$ has no effect acutely, on the GH secretion of pubertal boys.

Serum estradiol levels were determined in three boys during $T$ infusion, and all values were below the level of sensitivity of the assay. Inasmuch as estradiol is known to enhance GH secretion $(9,12), \mathrm{T}$ aromatization to estradiol may be required to produce increased $\mathrm{GH}$ secretion in boys. The presumptive role of estradiol in promotion of growth has been recently reviewed (25). Alternatively, increased $\mathrm{GH}$ secretion in puberty may be due to a maturational event that is independent of the increase in $\mathrm{T}$ but is temporally related to its increase. This seems less likely in view of the recent study of Chalew et al. (16) who have shown that in children with constitutional growth delay, $\mathrm{GH}$ secretion declines after $\mathrm{T}$ administration is stopped, despite the physical maturation of the boys in the study.

The overall mean $\mathrm{GH}$ concentration in the boys studied was $3.4 \mu \mathrm{g} / \mathrm{L}$ which is less than reported nighttime mean $\mathrm{GH}$ values of $6-7 \mu \mathrm{g} / \mathrm{L}$ in prepubertal healthy children $(6,7)$. In a study by Bierich (26) nighttime mean $\mathrm{GH}$ concentrations for children with constitutional growth delay were in the range of normal control subjects but were $53 \%$ of the control group. Bierich (26) suggested that boys with constitutional delay of growth may secrete relatively less $\mathrm{GH}$ than their normally maturing agemates. Whether the relative decrease in GH secretion is secondary to a pathologic process occurring in boys with constitutional delay of growth or is a reflection of their pubertal status and/or sex hormone milieu is as yet unknown. Thus it is conceivable that boys with normal GH concentration and normal onset of adolescence might have an altered response to $\mathrm{GH}$ to $\mathrm{T}$, unlike our subjects.

Nongonadal anabolic steroids, such as oxandrolone, have also been given to children to enhance their growth velocity. The increase in velocity has not been associated with a change in $\mathrm{GH}$ secretion nor with an increase in SmC concentration, in boys with constitutional delay of growth (10). Thus androgens such as oxandrolone, and perhaps T, may exert a primary effect on growth by a direct effect on skeletal tissue rather than by enhancing GH secretion. The increase in serum GH concentration after chronic administration of $\mathrm{T}$ may be due to its conversion to estradiol which then may enhance $\mathrm{GH}$ secretion.

We did not find a correlation between $\mathrm{GH}$ and ht or growth velocity. Albertsson-Wikland and Rosberg (27) found a nonlinear correlation between $h t$ and mean GH concentration for pubertal children $(r=0.36)$ but the correlation was much more striking for the prepubertal children where a linear correlation $(r$ $=0.69$ ) was found. A correlation of mean $\mathrm{GH}$ and ht was not found in our pubertal subjects, perhaps due to our small sample size or the presence of constitutional growth delay. In our study, GH pulse area, but not mean concentration or pulse amplitude, was positively correlated with $\mathrm{SmC}$ concentration. The significance of this observation is unclear but perhaps indicates that the size of a $\mathrm{GH}$ pulse is better related to the $\mathrm{GH}$ induced rise in $\mathrm{SmC}$ than is the mean serum GH content. SmC was also positively associated with pubertal stage in agreement with previous observations (28).

In this study we have found that, in pubertal children with constitutional growth delay, short-term infusion of $T$ does not acutely alter the release of $\mathrm{GH}$ by the pituitary nor is there an amplification of $\mathrm{GH}$ pulse area. Thus, long-term exposure to $\mathrm{T}$ or the secretion of, or conversion to, other pubertal sex steroids such as estradiol may be required to produce the increase in $\mathrm{GH}$ pulse amplitude which may be associated with increased growth at puberty. Alternative hypotheses to be explored are that the increased growth velocity observed during $T$ therapy may be related to sex steroid modulation of $\mathrm{GH}$ bioactivity or that there may be alterations in $\mathrm{GH}$ binding protein which may make more unbound $\mathrm{GH}$ available at target tissue $\mathrm{GH}$ receptors.

\section{REFERENCES}

1. Glick SM, Roth J, Yalow RS, Berson SA 1965 The regulation of growth hormone secretion. Rec Prog Hormone Res 21:241-283

2. Finkelstein JW, Boyar RM, Roffwarg HP, Kream J, Hellman L 1972 Agerelated change in the twenty-four-hour spontaneous secretion of growth hormone. J Clin Endocrinol Metab 35:665-670

3. Plotnick LP, Thompson RG, Kowarski A, de Lacerda L, Migeon CJ, Blizzard RM 1975 Circadian variation of integrated concentrations of growth hormone in children and adults. J Clin Endocrinol Metab 40:240-247

4. Zadik Z, Chalew SA McCarter RJ Jr, Meistas M, Kowarski AA 1985 The influence of age on the 24-hour integrated concentration of growth hormone in normal individuals. J Clin Endocrinol Metab 60:513-516

5. Mauras N, Blizzard RM, Link K, Johnson ML, Rogol AD, Veldhuis JD 1987 Augmentation of growth hormone secretion during puberty: Evidence for a pulse amplitude phenomenon. J Clin Endocrinol Metab 64:596-601

6. Bercu B 1988 Growth hormone neurosecretory dysfunction: update. In: Bercu B, (ed) Basic and Clinical Aspects of Growth Hormone. Plenum Press, New York, pp 119-142

7. Richards GE, Cavallo A, Meyer WJ III 1987 Diagnostic validity of 12-hour integrated concentration of growth hormone. Am J Dis Child 141:553-555

8. Ho KY, Veldhuis JD, Johnson ML, Furlanetto R, Evans WS, Alberti KG, Thorner MO 1988 Fasting enhances growth hormone secretion and amplifies the complex rhythms of growth hormone secretion in man. J Clin Invest 81:968-975

9. Ho KY, Evans WS, Blizzard RM, Veldhuis JD, Merriam GR, Samojlik E, Furlanetto R, Rogol AD, Kaiser DL, Thorner MO 1987 Effects of sex and age on the 24-hour profile of growth hormone secretion in man: Importance of endogenous estradiol concentrations. J Clin Endocrinol Metabl 64:51-58

10. Link K, Blizzard RM, Evans WS, Kaiser DL, Parker MW, Rogol AD 1986 The effect of androgens on the pulsatile release and the twenty-four-hour mean concentration of growth hormone in peripubertal males. J Clin Endocrinol Metab 62:159-164

11. Miller JD, Tannenbaum GS, Colle E, Guyda HJ 1982 Daytime pulsatile growth hormone secretion during childhood and adolescence. J Clin Endocrinol Metab 55:989-994

12. Lippe B, Wong S-L R, Kaplan SA 1971 Simultaneous assessment of growth hormone and ACTH reserve in children pretreated with diethylstilbestrol. J Clin Endocrinol Metab 33:949-956

13. Martin LG, Clark JW, Connor TB 1968 Growth hormone secretion enhanced by androgens. J Clin Endocrinol Metab 28:425-428

14. Illig R, Prader A 1970 Effect of testosterone on growth hormone secretion in patients with anorchia and delayed puberty. J Clin Endocrinol Metab 30:615-618

15. Liu L, Merriam GR, Sherins RJ 1987 Chronic sex steroid exposure increases mean plasma growth hormone concentration and pulse amplitude in men with isolated hypogonadotropic hypogonadism. J Clin Endocrinol Metab 64:651-656

16. Chalew SA, Udoff LC, Hanukoglu A, Bistritzer T, Armour KM, Kowarski AA 1988 The effects of testosterone therapy on spontaneous growth hormone secretion in boys with constitutional delay. Am J Dis Child 142:1345-1348

17. Richman RA, Kirsch LR 1988 Testosterone treatment in adolescent boys with constitutional delay in growth and development. N Engl J Med 319:15631567

18. Hale PM, Khoury S, Foster CM, Beitins IZ, Hopwood NJ, Marshall JC, Kelch RP 1988 Increased luteinizing hormone pulse frequency during sleep: effects of testosterone infusion. $\mathrm{J}$ Clin Endocrinol Metab 66:785-791 
19. Foster CM, Mendes T, Hale PM, Beitins IZ, Hopwood NJ, Marshall J, Kelch RP 1988 Testosterone (T) infusion decreases LH pulse frequency in early to midpubertal boys. Pediatr Res 23:277A(abstr 454)

20. Greulich WW, Pyle SI 1955 Atlas of Skeletal Development of the Hand and Wrist. Stanford University Press, Stanford, CA

21. Tanner JM 1978 Growth at Adolescence. Blackwell, Oxford

22. Berson SA, Yalow RS, Glick SM, Roth J 1964 Immunoassays of Protein and Peptide Hormones. Metabolism 13:1135-1153

23. Oerter KE, Guardabasso V, Rodbard D 1986 Detection and characterization of peaks and estimation of instantaneous secretory rate for episodic pulsatile hormone secretion. Comput Biomed Res 19:170-191

24. Bardin CW 1986 Pituitary-testicular axis. In: Yen SSC, Jaffe RB (eds) Repro- ductive Endocrinology: Physiology, Pathophysiology and Clinical Management. WB Saunders, Philadelphia, pp 177-199

25. Bourguignon J-P 1988 Linear growth as a function of age at onset of puberty and sex steroid dosage: therapeutic implications. Endocrine Rev 9:467-488

26. Bierich JR 1988 Constitutional delay of growth and adolescent development. In: Bercu BB ed. Basic and Clinical Aspects of Growth Hormone. Plenum, New York pp 289-302

27. Albertsson-Wikland K, Rosberg S 1988 Analyzes of 24-hour growth hormone profiles in children: Relation to growth. J Clin Endocrinol Metab 67:493500

28. Rosenfield RL, Furlanetto R, Bock D 1983 Relationship of somatomedin-C concentrations to pubertal changes. J Pediatr 103:723-728 